\title{
COMMENTARY
}

\section{Empowerment, love, and connection: Lessons learned from the Farmacy Project, a food-is-medicine program in Rutland, Vermont}

\author{
Emma Hileman* \\ Vermont Farmers Food Center
}

Submitted May 27, 2021 / Published online November 18, 2021

Citation: Hileman, E. (2021). Empowerment, love, and connection: Lessons learned from the Farmacy Project, a food-is-medicine program in Rutland, Vermont. Journal of Agriculture, Food Systems, and Community Development, 11(1), 11-13. https://doi.org/10.5304/jafscd.2021.111.011

Copyright (C) 2021 by the Author. Published by the Lyson Center for Civic Agriculture and Food Systems. Open access under CC-BY license.

S enior high school student volunteer Tyler Carroll walks out to the car that has pulled up along the back of the renovated former iron works building, the site of the Vermont Farmers Food Center, in downtown Rutland, Vermont. Tyler says, "Hil Can I get your name, please?" Tyler then takes one bag from the table covered with bagged farm shares and puts one in the customer's back seat, thanking them as they drive off with their local goods.

The members are here to receive their produce prescription through the Farmacy Project, a program that provides 150 individuals in the county with 15 weeks of fresh produce grown exclusively by local Rutland county farms. Finishing up its sixth year in 2021, the program has become a standard in the area, working with healthcare providers who identify individuals with chronic diet-related health conditions who could benefit from a "food as medicine" produce share. This project intersects community health and local agriculture. Many, although not all, members may be food insecure as well, as reflected in the $68 \%$ of members this year who were food insecure based on the results of the two-item food insecurity questionnaire of the U.S. Household Food Security Survey. ${ }^{1}$

Since 2015, the program has worked with community partners to provide nutrition education for members while investing over US $\$ 150,000$ back into the local agricultural economy. Farmacy is one of the most established programs at the Vermont Farmers Food Center, a 501(c)(3) nonprofit whose mission is to increase access to and availability of locally produced food in the Rutland region through

* Emma Hileman, Farmacy Project Director, Vermont Farmers Food Center; P.O. Box 1008; Rutland, VT 05701 USA;

+1-802-342-4219; hileman@vermontfarmersfoodcenter.org

${ }^{1}$ https://www.ers.usda.gov/topics/food-nutrition-assistance/food-security-in-the-us/survey-tools/ 
education, expanding markets and market access, aggregation, and distribution of locally produced and value-added agricultural products.

For Mike and Karen King, moving up to Rutland County, Vermont, from Massachusetts changed their lives. You can regularly see Mike, 59, and Karen, 61, traveling to a nearby town to check out a new hiking trail or see Mike zooming around on an ebike rented from the local recreation department. But when they moved to the area just a few years ago, Mike, who is diabetic, was told by his doctor that he needed to go on four new medications. Karen was using a wheelchair because she was unable to walk for more than a few minutes. What helped them change was the presence of dedicated community programs, including ours. Introduced to this food-as-medicine program by their doctor, Mike is down 60 lbs. and only takes one medication. Karen has lost $70 \mathrm{lbs}$. and now walks and hikes regularly using only a cane for support. Their story resonates with many of our other program members, and during the tumultuous times created by COVID-19, it is stories like these that keep our staff going.

Running the Farmacy Project in 2020-2021 has had its tough moments, much like all nonprofit programs navigating a year defined by a pandemic and social isolation. Community programs thrive on just that — community_-so how do you continue to form community when getting together is the very thing you aren't able to do? The answer is simply that you do your best.

With the help of many partnerships built the year before through a partnership with the Rutland Free Clinic and their outreach to rural communities, we were able to expand the Farmacy Project to four new locations in the outer reaches of the county. With the help of dedicated volunteers, we reached over 428 people in 150 households from July through December 2020. Although we had to adjust our inperson pick-up process, instead running a curbside service and not offering our normal cooking classes and demos, we still made what connections we could with our participants. What we missed this year had nothing to do with the vegetables - we were still able to purchase over 18,000 pounds of produce from our farm partners-but what we couldn't as easily cultivate were the things not visibly seen but the most important components of our program: empowerment, love, and connection.

Mike and Karen wouldn't be where they are today in their journey to health if it weren't for themselves. Their success didn't just appear because we did the work for them with our program, instead, their self-empowerment was fostered each week when they received a bag of produce with new and interesting vegetables and tried the recipes given in every share. According to Mike, "I try to go in with an open mind and try everything. I was never raised on vegetables. Learning all these things I did was an eye opener. We had a delicious butternut squash soup last fall and I was shocked at how good it was. Since then we've learned how to use a whole butternut squash and some people think it's not a big deal ... but it is if you've never eaten them before." This also led them to seek out other local wellness programs focused on exercise like Come Alive Outside, which "inspires collaborative community systems that create the awareness, intention, and opportunity for people to live healthier lives outside." That empowerment has always been a crucial part of the success of our food-as-medicine program. Another participant, the primary caregiver to her developmentally challenged granddaughter, remarked last year, "it's very empowering when I look in the bag and go 'oh my god I can use this for her," sharing that she learned to add greens to smoothies to increase the nutrition in her granddaughter's diet.

And when it comes to love there isn't a better story than that of Frank Wallace and Dolly Cole, who met during their first week of becoming members of the Farmacy Project back in 2015 and now are a couple living together and sharing their wealth of knowledge about the power of food as medicine. But it's not only romantic love that has been cultivated by our program; love for community has been as well. During a focus group held with members at the farm center prior to the pandemic, Frank remarked, "My feeling is that's what programs like this is all about, helping each other out, you know it's being sociable, it's having somebody during the week to say hey, how ya doin'? And you know it makes a 
difference in your life." Though the program focuses on the power of local, healthy, and whole foods, it is clear from stories like these that it means even more to those who dedicate themselves and follow through every week to simply show up.

What programs like the Farmacy Project do well is create a link between farm viability and public health while weaving together educational and cultural experiences, something that only people-centered, place-based programming can provide. Food thus becomes not only a tool but also a catalyst for communitywide social change. This brings us to the third and maybe most important outcome for Farmacy: connection. During the first five years of the program and even after the most memorable sixth year, connections have been made that strengthen all the participating parties, including farmers, volunteers, and members. Whether it is a community member delivering a share to a homebound individual, or a family learning how to make sauerkraut during a cooking class, or a member sharing a favorite recipe that goes around in the weekly newsletter, or our volunteers greeting someone by name every week as they pull up in their car with masks on, the connections deepen and become more than just handing out healthy and nutritious food. Local food-as-medicine programs (of which there are others in the state) foster these connections and even have led our members to know the farmers who are working to help nourish their bodies. Frank Wallace appreciates the connections he has made with the farm partners, saying, "It makes me feel good to talk to them [farmers] and get to know them and let them know that their vegetables are helping a lot."

It is our hope as we move forward to maintain, if not expand, these elements of empowerment, love, and connection found so effortlessly in our program and continue to use local food as the powerful tool for social change that it can be and should be around the nation and in our world.

For more information on the Farmacy Project, a program of the Vermont Farmers Food Center, visit https://www.vermontfarmersfoodcenter.org/farmacy project

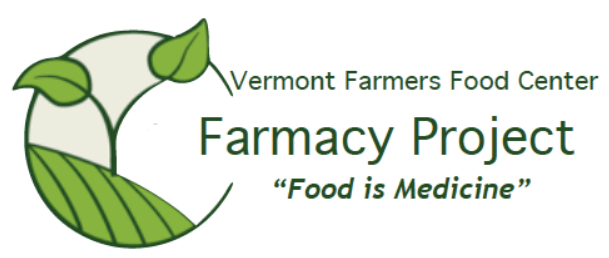

